\title{
Analisis Portofolio Untuk Menentukan Expected Return Optimal dan Risiko Minimal pada Saham Perusahaan Telekomunikasi yang Terdaftar di Bursa Efek Indonesia
}

\author{
Ratih Paramitasari \\ Jurusan Akuntansi, Fakultas Ekonomi \\ Universitas Terbuka \\ UPBJJ-UT Surakarta 57554 \\ e-mail: ratih_paramita@ut.ac.id \\ Mulyono \\ Jurusan PKLH, FKIP \\ Universitas Terbuka \\ UPBJJ-UT Surakarta 57554
}

\begin{abstract}
Investment is investing some amount of funds in the form of money or goods, expected to obtain results in the future. Investors do not positively know the results of their investment, thus an investor is at risk in the investment made. The approach, that can be made by investors to face such a risk, is by conducting calculation in selecting a portfolio and investor behavior patterns towards stocks transaction. Portfolio is fund allocated to various investment alternatives, or diversified in some financial assets, so that the overall investment risks can be minimized. This study aims to find empirical evidence for alternative investments resulting in optimal expected returns and investment risk elimination. In addition, it identifies the optimal portfolio combinations that are formed by the stocks of telecommunication categories. The approach of this study is using expected return and risks resulting from the combination of stock portfolios. The populations of this study are stock companies of telecommunication categories according to Indonesia Stock Exchange (IDX) statistics period of 2009 to 2011 with a purposive sampling method. Based on the results of this research, there are five companies that can be formed into a stock portfolio with a combination of 2 shares to 5 shares. All of the form combinations of stocks were then rated based on the value of coefficient of variance (CV). The optimal portfolio is a portfolio with the smallest CV value. From the result with Single Index Model and Equally Weighted Method, it was found that the combinations of two stocks have the smallest $\mathrm{CV}$ value; that is, a combination of shares of Bakrie Telecom, Tbk and XL Axiata, Tbk.

Keywords: expected return, risk, portfolio, coefficient of variance, stock companies
\end{abstract}

\begin{abstract}
ABSTRAK
Investasi merupakan penanaman sejumlah dana dalam bentuk uang maupun barang yang diharapkan akan memberikan hasil di kemudian hari. Investor tidak mengetahui dengan pasti hasil yang akan diperoleh dari investasi yang mereka lakukan. Dalam keadaan semacam itu dapat dikatakan bahwa investor tersebut menghadapi risiko dalam investasi yang dilakukan. Langkah pendekatan yang dapat dilakukan oleh para investor dalam menghadapi risiko investasi adalah melakukan penghitungan dalam pemilihan dan penentuan portofolio serta pola perilaku investor di bursa dalam transaksi jual beli saham. Hakikat pembentukan portofolio adalah mengalokasikan dana pada berbagai alternatif investasi atau melakukan diversifikasi pada beberapa aktiva finansial, sehingga risiko investasi secara keseluruhan akan dapat diminimalkan. Penelitian ini bertujuan untuk menemukan bukti empiris untuk mendapatkan alternatif investasi saham yang menghasilkan expected return saham yang optimal dan menurunkan risiko investasi yang minimal. Penelitian ini mengidentifikasi kombinasi portofolio optimal yang dapat
\end{abstract}


dibentuk dari saham perusahaan kategori telekomunikasi. Metode pendekatan dalam penelitian ini adalah dengan tingkat keuntungan yang diharapkan (expected return) dan risiko yang dihasilkan dari kombinasi portofolio saham. Penelitian ini dilakukan di Indonesia dengan populasi adalah saham perusahaan yang masuk dalam kategori telekomunikasi menurut statistik Bursa Efek Indonesia (BEI) periode tahun 2009 sampai dengan tahun 2011 dengan metode purposive sampling. Terdapat lima perusahaan yang dapat dibentuk menjadi portofolio saham dengan kombinasi antara 2 saham sampai dengan 5 saham. Dari semua kombinasi saham yang dapat dibentuk kemudian diperingkat berdasarkan nilai Coefficient of Variance (CV). Portofolio yang paling optimal adalah portofolio yang memiliki nilai CV terkecil. Dari hasil perhitungan dengan menggunakan Single Index Model dan Equally Weighted menunjukkan menunjukkan bahwa kombinasi 2 saham memiliki nilai CV terkecil yaitu kombinasi untuk saham PT. Bakrie Telecom, Tbk dan saham PT. XL Axiata, Tbk.

Kata kunci: expected return, risiko, portofolio, coefficient of variance, saham perusahaan

\section{Pendahuluan}

Investasi merupakan penanaman sejumlah dana dalam bentuk uang maupun barang yang diharapkan akan memberikan hasil di kemudian hari. Investasi dalam bentuk surat berharga (sekuritas) biasanya dapat dilakukan melalui pasar uang atau pasar modal. Pada umumnya tujuan investor berinvestasi di pasar modal adalah mengharapkan tingkat keuntungan lebih besar dibandingkan tingkat keuntungan di pasar uang yang ditanamkan dalam bentuk deposito (Astuti dan Sugiharto 2005).

Investor tidak mengetahui dengan pasti hasil yang akan diperoleh dari investasi yang dilakukan. Dalam keadaan semacam ini, dapat dikatakan bahwa investor tersebut menghadapi risiko dalam investasi yang dilakukan. Jogiyanto (2003) mengemukakan bahwa risiko investasi pada dasarnya merupakan penyimpangan tingkat keuntungan yang diperoleh dengan tingkat keuntungan yang diharapkan.

Harapan akan peran pasar modal sebagai wahana alternatif bagi investor dipengaruhi oleh faktor kemampuan investor memilih saham secara rasional dari cara memilih saham yang memberikan hasil (return) maksimum pada tingkat risiko tertentu atau mempunyai risiko minimum pada tingkat return tertentu. Langkah pendekatan yang dapat dilakukan para investor adalah melakukan penghitungan dalam pemilihan dan penentuan portofolio serta pola perilaku investor di bursa dalam transaksi jual beli saham (Harmono 1999). Hakikat pembentukan portofolio adalah mengalokasikan dana pada berbagai alternatif investasi atau melakukan diversifikasi pada beberapa aktiva finansial, sehingga risiko investasi secara keseluruhan akan dapat diminimalkan (Utomo 2007).

Burgess dan Bey (2014) menyebutkan pendekatan dalam pembentukan portofolio dengan menggunakan Model Indeks Tunggal (Single Index Model) telah digunakan oleh Elton, Gruber, dan Padberg tahun 1976. Prosedur Elton, Gruber, Padberg (EGP) mengasumsikan bahwa Single Index Model mendeskripsikan return untuk sekuritas individu. EGP terdiri dari tiga langkah, yaitu 1) merangking aset dengan reward to beta ratio; 2) menghitung cut off point; dan 3) menghitung komposisi (proporsi) portofolio yang diinvestasikan untuk setiap aset. Sudaryanto (2001) menyebutkan bahwa pemilihan saham dan penentuan portofolio optimal didasari oleh pendahulunya Markowitz pada tahun 1959 yang dimulai dari data historis atas saham individual yang dijadikan input, dan dianalisis untuk menghasilkan keluaran yang menggambarkan kinerja setiap portofolio, apakah tergolong portofolio optimal atau sebaliknya. 
Pettengill et al. (1995) melakukan pengujian hubungan antara beta dan return. Hasil penelitiannya menunjukkan adanya trade off positif antara beta dan rata-rata return portofolio. Lakonishok dan Shapiro (1984) menggunakan return saham sebagai fungsi linier antara beta dan risiko total, dan hasil penelitiannya menunjukkan bahwa return sekuritas individu tidak berhubungan dengan risiko sistematis.

Penelitian yang telah dilakukan mengenai pembentukan portofolio untuk meningkatkan return secara optimal dan menurunkan risiko investasi pernah dilakukan oleh Harmono (1999) dan Wardani (2010). Harmono (1999) melakukan penelitian dengan menggunakan model indeks tunggal untuk menganalisis portofolio yang dapat dijadikan dasar untuk menentukan saham yang menunjukkan tingkat return optimal dan risiko minimal dari saham perusahaan manufaktur yang terdaftar di Bursa Efek Surabaya mulai Desember 1995 sampai dengan Mei 1998.

Wardani (2010) melakukan penelitian dengan menggunakan model indeks tunggal untuk mengetahui portofolio yang optimal dan komposisi modal optimal pada saham-saham perusahaan yang terdaftar dalam Jakarta Islamic Index (JII) periode Oktober sampai dengan Desember 2008 dan periode Januari sampai dengan Maret 2009. Penentuan pembentukan portofolio optimal menggunakan perhitungan nilai Excess Return to Beta (ERB) dan nilai $C_{i}$. Nilai $C_{i}$ merupakan pembatas nilai ERB berapa yang dikatakan tinggi. Astuti dan Sugiharto (2005) melakukan penelitian untuk mengidentifikasi kombinasi portofolio optimal yang dibentuk dari lima saham perusahaan plastick and packaging selama periode tahun 1999 sampai dengan tahun 2003. Metode pendekatannya dengan tingkat keuntungan (return) dan risiko (standar deviasi) yang dihasilkan dari kombinasi portofolio.

Dari hasil penelitian di atas, peneliti ingin menganalisis kembali portofolio dengan menggunakan saham perusahaan yang masuk dalam kategori telekomunikasi. Perbedaan penelitian ini dengan penelitian-penelitian sebelumnya adalah penelitian ini menggunakan expected return karena dalam berinvestasi yang perlu dipertimbangkan oleh investor adalah risiko dan expected return dari investasi tersebut, serta pembentukan portofolio akan dibandingkan antara metode Single Index Model dengan metode equal weighted. Sedangkan pada penelitian-penelitian sebelumnya menggunakan return sebagai pendekatannya. Batasan masalah dalam penelitian ini adalah menganalisis portofolio dari saham perusahaan telekomunikasi yang terdaftar di Bursa Efek Indonesia periode tahun 2009 sampai dengan tahun 2011.

Masalah utama yang biasa dihadapi oleh manajer portofolio adalah ketika mengestimasi karakteristik risiko dan return atas sekuritas individu, dan mengkombinasikan estimasi risiko dan return sekuritas individual ke dalam portofolio optimal (Burgess dan Bey 2014). Penelitian ini bertujuan untuk menemukan bukti empiris menggunakan analisis portofolio untuk mendapatkan alternatif investasi saham yang menghasilkan expected return saham optimal dan meminimalkan risiko investasi.

\section{Metode Penelitian}

Data yang digunakan dalam penelitian ini adalah data sekunder yang diperoleh peneliti secara tidak langsung melalui media perantara oleh pihak lain. Sedangkan 
sumber data yang diperlukan dalam penelitian ini diperoleh dari sumber data eksternal, yaitu sumber data diperoleh dari luar obyek yang diteliti, antara lain :

1. IDX Monthly Statistic mulai tahun 2009 sampai dengan tahun 2011.

2. Laporan harga saham individu bulanan.

3. Laporan indeks harga saham gabungan (IHSG) bulanan. Data ini digunakan untuk mengetahui dan menentukan return pasar bulanan selama empat tahun.

4. BI Rate bulanan yang diperoleh dari www.bi.go.id. Data ini digunakan untuk menghitung return bebas risiko bulanan selama empat tahun.

5. Beta koreksi dan alfa saham.

Penelitian ini dilakukan di Indonesia dengan populasi adalah saham perusahaan yang masuk dalam kategori telekomunikasi yang terdaftar di Bursa Efek Indonesia (BEI). Populasi tersebut terdiri dari 6 perusahaan, yaitu PT. Bakrie Telecom, Tbk, PT. Indosat, Tbk, PT. Inovisi Infracom, Tbk, PT. Smartfren Telecom, Tbk, PT. Telekomunikasi Indonesia, Tbk, dan PT. XL Axiata, Tbk. Kriteria penentuan contoh dalam penelitian ini adalah sebagai berikut :

1. Perusahaan masuk dalam kategori telekomunikasi BEI selama tahun 2009 sampai dengan tahun 2011.

2. Saham perusahaan memiliki expected return lebih besar dari return bebas risiko [ $E\left(R_{i}\right)>R_{f}$ ]. Hal ini menunjukkan bahwa investasi pada aset berisiko (saham) akan lebih menarik jika dibandingkan dengan investasi pada aset bebas risiko.

3. Perusahaan memiliki beta pasar lebih besar dari nol $(\beta>0)$, artinya saham mempunyai kepekaan yang tinggi terhadap kondisi pasar.

4. Saham perusahaan yang memiliki nilai ERB yang lebih besar atau sama dengan nilai ERB di titik $C_{i}$ (Cut Off Point). Kriteria ini digunakan untuk menyeleksi saham-saham yang akan dimasukkan ke dalam kandidat portofolio yang efisien.

Langkah analisis data dalam penelitian ini sebagai berikut :

1. Variabel Terikat (Dependent Variable).

Variabel terikat diidentifikasi sebagai expected return saham dalam pembentukan portofolio optimal. Langkah-langkah untuk menentukan expected return saham dalam pembentukan portofolio optimal adalah sebagai berikut :

a. Menentukan return saham bulanan individu $\left(R_{i}\right)$ dengan rumus sebagai berikut :

$$
R_{i}=\frac{P_{i t}-P_{i t-1}}{P_{i t-1}} .
$$

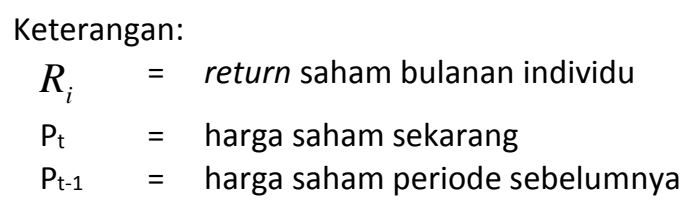

b. Menentukan return pasar $\left(\mathrm{R}_{m t}\right)$ dengan rumus sebagai berikut :

$$
\mathrm{R}_{m t}=\frac{I H S G_{t}-I H S G_{t-1}}{I H S G_{t-1}} .
$$


Keterangan:
$\mathrm{R}_{m t} \quad=$ return pasar
$\mathrm{IHSG}_{\mathrm{t}}=\mathrm{IHSG}$ sekarang
$\mathrm{IHSG}_{\mathrm{t}-1}=\mathrm{IHSG}$ periode sebelumnya

c. Menentukan expected return $E\left(R_{i}\right)$ saham individu sebagai berikut :

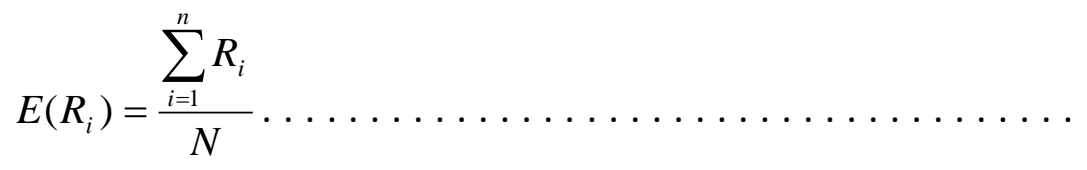

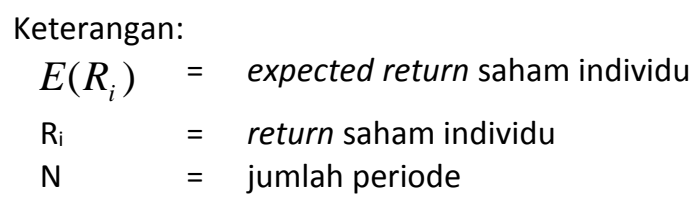

d. Menentukan return bebas risiko $\left(R_{f}\right)$ dengan menggunakan rata-rata suku bunga Sertifikat Bank Indonesia (SBI). Jika $E\left(R_{i}\right)>R_{f}$ maka saham tersebut akan terpilih dalam analisis selanjutnya, dan sebaliknya jika $E\left(R_{i}\right)<R_{f}$ maka saham tersebut tidak akan terpilih dalam proses selanjutnya.

e. Menentukan beta saham ( $\beta_{i}$ ) yang digunakan untuk mengukur risiko sistematis saham individual dan varians ei $\left(\sigma^{2} e i\right)$ yang digunakan untuk mengukur risiko tidak sistematis saham individual. Beta dan alfa dalam penelitian ini menggunakan beta koreksi dan alfa yang diperoleh dari Pusat Data dan Bisnis Ekonomi (PDBE) Fakultas Ekonomi UGM seperti yang dilakukan pada penelitian Winarto (2007). Alfa digunakan untuk menghitung varians ei $\left(\sigma^{2} e i\right)$ yang dihitung dengan menggunakan rumus sebagai berikut :

$$
\sigma_{e i}^{2}=\frac{1}{n} \sum_{i=1}^{n}\left(R_{i}-\left(\alpha_{i}+\beta_{i} \cdot R_{m t}\right)\right)^{2}
$$

Keterangan:

$$
\begin{aligned}
\sigma^{2} e i & \text { varians (risiko tidak sistematis) } \\
\mathrm{Ri} & =\text { return saham individu } \\
\alpha_{i} & =\text { alfa saham individu sebagai bagian return yang unik hanya berhubungan } \\
& \text { dengan peristiwa mikro } \\
\beta_{i} & =\text { beta saham individu sebagai pengukur risiko sistematis } \\
R_{m t} & =\text { return pasar }
\end{aligned}
$$

Jika $\beta_{i}>0$ maka saham tersebut terpilih dan dimasukkan dalam proses analisis selanjutnya, dan sebaliknya jika $\beta_{i}<0$ maka saham tersebut diabaikan karena akan menghasilkan ERB negatif yang berarti menghasilkan return saham di bawah return bebas risiko.

f. Menentukan ERB untuk menentukan return saham berada diatas atau dibawah return bebas risiko. ERB dihitung dengan rumus sebagai berikut :

$$
E R B_{i}=\frac{E\left(R_{i}\right)-R_{f}}{\beta_{i}}
$$


24|Paramitasari, Mulyono - Analisis Portofolio Untuk Menentukan Expected Return Optimal

Keterangan:

$\begin{array}{ll}E\left(R_{i}\right) & =\text { expected return saham individu } \\ R_{f} & =\text { return bebas risiko } \\ \beta_{i} & =\text { beta saham individu sebagai pengukur risiko sistematis }\end{array}$

g. Menentukan cut-off point $\left(C^{*}\right)$ dengan rumus sebagai berikut :

$$
C_{i}=\frac{\sigma_{m}{ }^{2} \cdot \sum_{j=1}^{i} A j}{1+{\sigma_{m}}^{2} \cdot \sum_{j=1}^{i} B j} .
$$

$C_{i}$ adalah nilai $\mathrm{C}$ untuk sekuritas ke-i yang dihitung dari akumulasi nilai-nilai $\mathrm{A} 1$ sampai $A_{i}$ dan nilai $B 1$ sampai $B_{i}$. Misalnya $C 3$ menunjukkan nilai $C$ untuk sekuritas ke-3, yang dihitung dari akumulasi $A 1, A 2, A 3$ dan $B 1, B 2, B 3$, dengan mensubtitusi nilai $\mathrm{Aj}$ dan $\mathrm{Bj}$ dengan rumus :

$$
\begin{gathered}
A j=\frac{\left[E\left(R_{i}\right)-R_{f}\right] \cdot \beta_{j}}{\sigma_{e j}{ }^{2}} . \\
B j=\frac{\beta_{j}{ }^{2}}{\sigma_{e j}{ }^{2}} \ldots \ldots \ldots \ldots
\end{gathered}
$$

Maka rumus $C_{i}$ menjadi :

$$
C_{i}=\frac{\sigma_{m}{ }^{2} \sum_{j=1}^{i} \frac{\left[E\left(R_{j}\right)-R_{f}\right] . \beta_{j}}{\sigma_{e j}{ }^{2}}}{1+\sigma_{m}{ }^{2} \sum_{j=1}^{i} \frac{\beta_{j}{ }^{2}}{\sigma_{e j}}}
$$

Keterangan:

$\sigma_{m}^{2}=$ Varians dari return indeks pasar

$E\left(R_{j}\right) \quad=$ expected return saham individu

$R_{f} \quad=$ return bebas risiko

$\beta_{j} \quad=$ beta saham individu sebagai pengukur risiko sistematis

$\sigma_{e j}{ }^{2}=$ varians sebagai pengukur risiko tidak sistematis

h. Setelah semua saham dirangking menurut nilai ERB-nya, selanjutnya masingmasing saham akan diseleksi berdasarkan cut off point-nya. Perhitungan $C_{i}$ dimulai dengan saham yang mempunyai nilai ERB tertinggi hingga ditemukan cut off point $\left(C_{i}\right)$. Nilai cut off point menentukan batas nilai ERB berapa yang dikatakan tinggi untuk menyeleksi saham-saham yang akan dimasukkan ke dalam portofolio. Saham-saham yang memiliki nilai ERB lebih besar atau sama dengan nilai ERB di titik $C_{i}$ akan dimasukkan ke dalam kandidat portofolio dan 
sebaliknya saham-saham yang memiliki nilai ERB lebih kecil dari nilai ERB di titik $C_{i}$ tidak dimasukkan ke dalam kandidat portofolio.

i. Menentukan proporsi dana pada masing-masing saham yang membentuk portofolio saham dengan rumus sebagai berikut :

$$
W_{i}=\frac{Z_{i}}{\sum_{j=1}^{k} Z_{j}}
$$

Dengan mensubsitusi $Z_{i}=\frac{\beta_{i}}{\sigma_{e i}{ }^{2}}\left(E R B_{i}-C_{i}\right)$

Keterangan:

$\mathrm{W}_{\mathrm{i}}=$ persentase alokasi dana untuk setiap sekuritas

$\sigma^{2} e i=$ varians (risiko tidak sistematis)

$\beta_{i}=$ beta saham individu sebagai pengukur risiko sistematis

$E R B_{i}=$ Excess Return to Beta sekuritas ke-i

$\mathrm{C}_{\mathrm{i}} \quad=$ cut off point

$\mathrm{Z}_{\mathrm{j}} \quad=$ akumulasi $\mathrm{Z}_{1}, \mathrm{Z}_{2}, \mathrm{Z}_{3}, \ldots, \mathrm{Zn}$

j. Membentuk alfa portofolio dan beta portofolio dengan rumus sebagai berikut :

$$
\begin{gathered}
\alpha_{p}=\sum_{i=1}^{n} W_{i} \cdot \alpha_{i} . \\
\beta_{p}=\sum_{i=1}^{n} W_{i} \cdot \beta_{i}
\end{gathered}
$$

Keterangan:

$\mathrm{W}_{\mathrm{i}}=$ persentase alokasi dana untuk setiap sekuritas

$\alpha_{i} \quad=$ alfa saham individu sebagai bagian return yang unik hanya berhubungan dengan peristiwa mikro

$\beta_{i} \quad=$ beta saham individu sebagai pengukur risiko sistematis

k. Menghitung risiko dari portofolio $\left(\sigma_{P}{ }^{2}\right)$ dengan rumus sebagai berikut :

$$
\sigma_{P}^{2}=\beta_{P}^{2} \cdot \sigma_{m}^{2}+\left(\sum_{i=1}^{n} W_{i} \cdot \sigma_{e i}\right)^{2}
$$

Keterangan:

$\beta_{P} \quad=$ beta portofolio yang merupakan sensitivitas return portofolio terhadap return pasar

$\sigma_{m}^{2}=$ varian return pasar

$\sigma^{2} e i=$ varians sebagai pengukur risiko tidak sistematis

I. Menghitung expected return portofolio $E(R p)$ dengan rumus sebagai berikut :

$$
E(R p)=\alpha_{p}+\beta_{p} \cdot E\left(R_{m}\right)
$$

Keterangan:

$\alpha_{p} \quad=$ alfa portofolio sebagai bagian return yang unik hanya berhubungan dengan peristiwa mikro

$\beta_{P} \quad=$ beta portofolio yang merupakan sensitivitas return portofolio terhadap return pasar

$E\left(R_{m}\right) \quad=$ expected return pasar 
m. Menghitung coefficient of variance (CV) untuk menentukan portofolio optimal dengan rumus sebagai berikut :

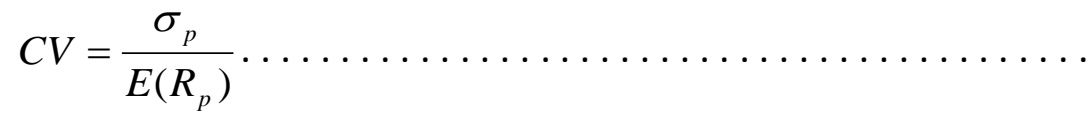

Keterangan:

$$
\begin{array}{ll}
\mathrm{CV} & =\text { coefficient of variance } \\
\sigma_{p} & =\text { risiko portofolio } \\
E\left(R_{p}\right) & =\text { expected return portofolio }
\end{array}
$$

Penghitungan portofolio dengan metode equally weighted sama seperti langkahlangkah diatas, yang berbeda pada langkah perhitungan proporsi dana pada masingmasing saham yang membentuk portofolio saham, yaitu dengan seluruh saham dalam portofolio memiliki bobot yang sama secara prorata berdasarkan jumlah data.

\section{Hasil Dan Pembahasan}

III.1. Penentuan Contoh dan Perhitungan Expected Return

Pada penelitian ini, penentuan contoh menggunakan purposive sampling dan diperoleh lima perusahaan kategori telekomunikasi yaitu PT. Bakrie Telecom, Tbk, PT. Indosat, Tbk, PT. Smartfren Telecom, Tbk, PT. Telekomunikasi Indonesia, Tbk, dan PT. XL Axiata, Tbk. Sedangkan PT. Inovisi Infracom, Tbk tidak dimasukkan ke dalam contoh karena PT. Inovisi Infracom, Tbk listing di Bursa Efek Indonesia mulai pertengahan tahun 2009. Sedangkan contoh yang dibutuhkan untuk penelitian ini mensyaratkan perusahaan harus sudah terdaftar di Bursa Efek Indonesia antara tahun 2009 sampai dengan 2011.

Perhitungan actual return setiap perusahaan didasarkan pada perubahan harga penutupan (closing price) saham mingguan mulai periode tahun 2009 sampai dengan tahun 2011. Berdasarkan rumus perhitungan expected return, varians, dan standar deviasi investasi, maka diperoleh hasil perhitungan seperti pada Tabel 1 dan Tabel 2. Dari lima perusahaan, yang memiliki expected return tertinggi adalah PT. XL Axiata, Tbk sebesar 0.014015, dan yang memiliki expected return terendah dimiliki oleh PT. Smartfren Telecom, Tbk sebesar 0.000570. Dari contoh perusahaan, tidak ada perusahaan yang menghasilkan expected return negatif. Dalam proses ini, semua contoh diikutkan dalam proses selanjutnya, karena sesuai dengan tujuan investor yang ingin memaksimalkan keuntungan.

Tabel 1. Hasil perhitungan expected return saham

\begin{tabular}{lc}
\hline \multicolumn{1}{c}{ Perusahaan } & Nilai Expected Return \\
\hline PT. Bakrie Telecom, Tbk & 0.012837 \\
PT. Indosat, Tbk & 0.001098 \\
PT. Smartfren Telecom, Tbk & 0.000570 \\
PT. Telekomunikasi Indonesia, Tbk & 0.000834 \\
PT. XL Axiata, Tbk & 0.014015 \\
\hline
\end{tabular}

Sumber: Data diolah 
Dari hasil perhitungan expected return di atas menunjukkan bahwa perusahaan yang menerima expected return tertinggi adalah PT. XL Axiata, Tbk sebesar 0.014015, sedangkan perusahaan yang menghasilkan expected return terkecil adalah perusahaan PT. Smartfren Telecom, Tbk sebesar 0.00570 .

Tabel 2. Hasil perhitungan standar deviasi

\begin{tabular}{lc}
\hline \multicolumn{1}{c}{ Perusahaan } & Nilai Standar Deviasi \\
\hline PT. Bakrie Telecom, Tbk & 0.071558 \\
PT. Indosat, Tbk & 0.053044 \\
PT. Smartfren Telecom, Tbk & 0.035495 \\
PT. Telekomunikasi Indonesia, Tbk & 0.037292 \\
PT. XL Axiata, Tbk & 0.087378 \\
\hline
\end{tabular}

Sumber: Data diolah

Dari hasil perhitungan standar deviasi di atas menunjukkan bahwa perusahaan yang memiliki standar deviasi tertinggi adalah PT. XL Axiata Tbk sebesar 0.087378, yang artinya saham ini memiliki risiko tertinggi, sedangkan perusahaan yang menghasilkan standar deviasi terkecil adalah perusahaan PT. Smartfren Telecom, Tbk sebesar 0.00570 , yang artinya saham ini memiliki risiko terendah.

\section{III.2. Penentuan Portofolio Optimal dengan Single Index Model}

Untuk menentukan tingkat keuntungan yang diharapkan (expected return) dan deviasi standar untuk kombinasi portofolio saham untuk menentukan portofolio yang optimal, maka hasil perhitungan expected return dan standar deviasi dimasukkan ke rumus (2) dan rumus (3). Untuk menentukan portofolio optimal menggunakan coefficient of variance (CV) yang memberikan peringkat pada setiap jenis kombinasi saham. Portofolio optimal adalah portofolio yang memiliki CV terkecil berdasarkan peringkat dari semua kombinsi portofolio.

Berdasarkan hasil perhitungan portofolio optimal dengan menggunakan Single Index Model, berikut ini disajikan Tabel 3 yang menunjukkan peringkat lima besar portofolio optimal dari kombinasi-kombinasi saham mulai dari kombinasi 2 saham sampai dengan kombinasi 5 saham.

Tabel 3. Peringkat portofolio optimal kombinasi 2 saham

\begin{tabular}{cccccccc}
\hline \multirow{2}{*}{ No } & $\begin{array}{c}\text { Kombinasi } \\
\text { Saham }\end{array}$ & A & B & C & D & E & \multirow{2}{*}{ CV } \\
\hline 1. & AE & 0.603865 & - & - & - & 0.396135 & 11.95 \\
2. & AB & 0.311432 & 0.688568 & - & - & - & 26.21 \\
3. & BE & - & 0.771188 & - & - & 0.228812 & 34.64 \\
4. & AD & 0.181888 & - & - & 0.818112 & - & 36.08 \\
5. & AC & 0.167069 & - & 0.832931 & - & - & 40.87 \\
\hline
\end{tabular}

Sumber: Data diolah

Keterangan :

$\begin{aligned} \mathrm{A} & =\text { PT. Bakrie Telecom, Tbk } \\ \mathrm{B} & =\text { PT. Indosat, Tbk } \\ \mathrm{C} & =\text { PT. Smartfren Telecom, Tbk } \\ \mathrm{D} & =\text { PT. Telekomunikasi Indonesia, Tbk } \\ \mathrm{E} & =\text { PT. XL Axiata, Tbk }\end{aligned}$


Dari hasil perhitungan portofolio optimal kombinasi 2 saham, menunjukkan bahwa kombinasi saham yang paling optimal adalah kombinasi perusahaan dengan CV terkecil yaitu kombinasi saham PT. Bakrie Telecom, Tbk dan PT. XL Axiata, Tbk dengan nilai CV sebesar 11.95.

Tabel 4. Peringkat portofolio optimal kombinasi 3 saham

\begin{tabular}{cccccccc}
\hline \multirow{2}{*}{ No } & Kombinasi & \multicolumn{7}{c}{ Proporsi Dana (\%) } & \multirow{2}{*}{ CV } \\
\cline { 3 - 7 } & Saham & A & B & C & D & E & \\
\hline 1. & ABE & 0.2586 & 0.571758 & - & - & 0.169641 & 33.51523 \\
2. & ADE & 0.162499 & - & - & 0.730903 & 0.106599 & 46.83942 \\
3. & ACE & 0.150567 & - & 0.750661 & - & 0.098772 & 51.91541 \\
4. & ABD & 0.129721 & 0.286809 & - & 0.583471 & - & 65.63423 \\
5. & ABC & 0.122003 & 0.269745 & 0.608252 & - & - & 72.46993 \\
\hline
\end{tabular}

Sumber: Data diolah

Keterangan :

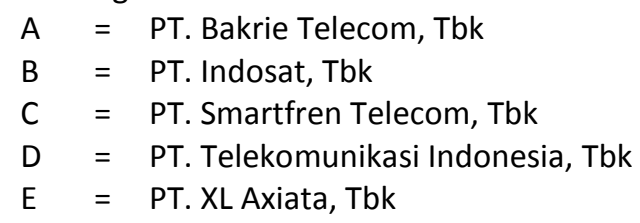

Dari hasil perhitungan portofolio optimal kombinasi 3 saham, menunjukkan bahwa kombinasi saham yang paling optimal adalah kombinasi perusahaan dengan CV terkecil yaitu kombinasi PT. Bakrie Telecom, Tbk, PT. Indosat, Tbk dan PT. Smartfren Telecom, Tbk dengan nilai CV sebesar 33.5.

Tabel 5. Peringkat portofolio optimal kombinasi 4 saham

\begin{tabular}{cccccccc}
\hline \multirow{2}{*}{ No } & Kombinasi & \multicolumn{7}{c}{ Proporsi Dana (\%) } & \multirow{2}{*}{ CV } \\
\cline { 3 - 7 } & Saham & A & B & C & D & E & \\
\hline 1. & ABDE & 0.119548 & 0.264316 & - & 0.537713 & 0.078423 & 48.008 \\
2. & ABCE & 0.112962 & 0.249756 & 0.563178 & - & 0.074103 & 51.913 \\
3. & ACDE & 0.089771 & - & 0.447558 & 0.403781 & 0.05889 & 56.175 \\
4. & BCDE & - & 0.17902 & 0.403674 & 0.36419 & 0.053115 & 85.324 \\
5. & ABCD & 0.078775 & 0.174169 & 0.001296 & 0.354321 & - & 131.713 \\
\hline
\end{tabular}

Sumber: Data diolah

Keterangan :

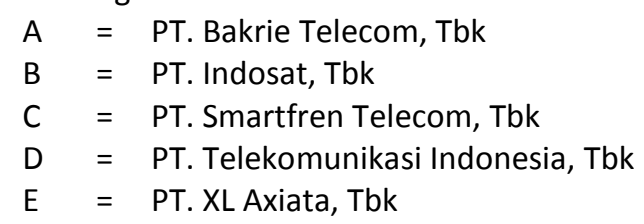

Dari hasil perhitungan portofolio optimal kombinasi 4 saham, menunjukkan bahwa kombinasi saham yang paling optimal adalah kombinasi perusahaan dengan CV terkecil yaitu kombinasi PT. Bakrie Telecom, PT. Indosat, PT. Telekomunikasi Indonesia, dan PT. XL Axiata dengan nilai CV sebesar 48. 
Tabel 6. Peringkat portofolio optimal kombinasi 5 saham

\begin{tabular}{|c|c|c|c|c|c|c|c|}
\hline \multirow{2}{*}{ No } & \multirow{2}{*}{$\begin{array}{c}\text { Kombinasi } \\
\text { Saham }\end{array}$} & \multicolumn{5}{|c|}{ Proporsi Dana (\%) } & \multirow{2}{*}{ CV } \\
\hline & & A & B & C & D & $\mathbf{E}$ & \\
\hline 1. & ABCDE & 0.074904 & 0.16561 & 0.3734 & 0.33691 & 0.04914 & 153.701 \\
\hline
\end{tabular}

Sumber: Data diolah

Keterangan :
$\mathrm{A}=\mathrm{PT}$. Bakrie Telecom, Tbk
$\mathrm{B}=\mathrm{PT}$. Indosat, Tbk
$\mathrm{C}=\mathrm{PT}$. Smartfren Telecom, Tbk
$\mathrm{D}=\mathrm{PT}$. Telekomunikasi Indonesia, Tbk
$\mathrm{E}=\mathrm{PT} . \mathrm{XL}$ Axiata, Tbk

Dari hasil perhitungan portofolio optimal kombinasi 5 saham menghasilkan nilai CV sebesar 153.7 yang terdiri dari saham PT. Bakrie Telecom, Tbk, PT. Indosat, Tbk, PT. Smartfren Telecom, Tbk, PT. Telekomunikasi Indonesia, Tbk, dan PT. XL Axiata, Tbk.

III.3. Penentuan Peringkat Portofolio Optimal dari Semua Kombinasi dengan Single Index Model

Penentuan protofolio yang paling optimal adalah dengan pemeringkatan kombinasi portofolio optimal bedasarkan nilai Coefficient of Variance (CV) terkecil. Berikut ini disajikan hasil pemeringkatan portofolio optimal berdasarkan Coefficient of Variance (CV) terkecil dari kombinasi 2 saham sampai dengan kombinasi 5 saham.

Tabel 7. Peringkat portofolio optimal kombinasi 2 saham sampai dengan 5 saham

\begin{tabular}{cccccccc}
\hline No & $\begin{array}{c}\text { Kombinasi } \\
\text { Saham }\end{array}$ & A & B & C & D & E & CV \\
\hline 1. & $\mathrm{AE}$ & 0.603865 & - & - & - & 0,396135 & 11,95 \\
2. & $\mathrm{ABE}$ & 0.2586 & 0.571758 & - & - & 0.169641 & 33.515 \\
3. & $\mathrm{ABDE}$ & 0.119548 & 0.264316 & - & 0.537713 & 0.078423 & 48.008 \\
4. & $\mathrm{ABDE}$ & 0.119548 & 0.264316 & - & 0.537713 & 0.078423 & 48.008 \\
5. & $\mathrm{ABCDE}$ & 0.074904 & 0.16561 & 0.3734 & 0.33691 & 0.04914 & 153.701 \\
\hline
\end{tabular}

Sumber: Data diolah

Keterangan :

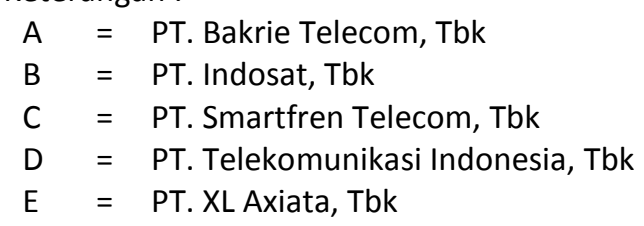

Tabel 7 di atas menggambarkan peringkat kombinasi portofolio paling optimal dari masing-masing kategori kombinasi 2 saham sampai dengan kombinasi 5 saham. Dari lima peringkat diatas, dapat dilihat bahwa portofolio yang paling optimal dari semua kombinasi portofolio adalah portofolio saham dengan kombinasi 2 saham, yaitu saham A (PT. Bakrie Telecom, Tbk) dan saham E (PT. XL Axiata, Tbk). Kombinasi saham ini memiliki proporsi dana saham A sebesar $60.4 \%$ dan proporsi dana saham $E$ sebesar 39.6\%, dengan nilai CV sebesar 11.95 . 


\section{III.4. Penentuan Portofolio Optimal dengan Equally Weighted Method}

Berdasarkan hasil perhitungan portofolio optimal dengan menggunakan Equally Weighted Method, berikut ini disajikan hasil yang menunjukkan peringkat lima besar portofolio optimal dari kombinasi-kombinasi saham mulai dari kombinasi 2 saham sampai dengan kombinasi 5 saham.

Tabel 8. Peringkat portofolio optimal kombinasi 2 saham

\begin{tabular}{cccccccc}
\hline \multirow{2}{*}{ No } & $\begin{array}{c}\text { Kombinasi } \\
\text { Saham }\end{array}$ & A & B & C & D & E & \multirow{2}{*}{ CV } \\
\cline { 3 - 6 } 1. & AE & 0.5 & - & - & - & 0.5 & 11.83798 \\
2. & AD & 0.5 & - & - & 0.5 & - & 15.92419 \\
3. & AC & 0.5 & - & 0.5 & - & - & 15.96908 \\
4. & DE & - & - & - & 0.5 & 0.5 & 16.79252 \\
5. & CE & - & - & 0.5 & - & 0.5 & 16.84948 \\
\hline
\end{tabular}

Sumber: Data diolah

Keterangan :

$\mathrm{A}=\mathrm{PT}$. Bakrie Telecom, Tbk

$\mathrm{B}=\mathrm{PT}$. Indosat, Tbk

$\mathrm{C}=\mathrm{PT}$. Smartfren Telecom, Tbk

$\mathrm{D}=\mathrm{PT}$. Telekomunikasi Indonesia, Tbk

$\mathrm{E}=\mathrm{PT}$. XL Axiata, Tbk

Dari hasil perhitungan portofolio optimal kombinasi 2 saham, menunjukkan bahwa kombinasi saham yang paling optimal adalah kombinasi perusahaan dengan CV terkecil yaitu kombinasi saham PT. Bakrie Telecom, Tbk dan PT. XL Axiata, Tbk dengan nilai CV sebesar 11.84.

Tabel 9. Peringkat portofolio optimal kombinasi 3 saham

\begin{tabular}{cccccccc}
\hline \multirow{2}{*}{ No } & Kombinasi & \multicolumn{7}{c}{ Proporsi Dana (\%) } & \multirow{2}{*}{ CV } \\
\cline { 3 - 7 } & Saham & A & B & C & D & E & \\
\hline 1. & ADE & 0.33 & - & - & 0.33 & 0.33 & 21.47798 \\
2. & ACE & 0.33 & - & 0.33 & - & 0.33 & 21.48576 \\
3. & ABE & 0.33 & 0.33 & - & - & 0.33 & 22.98282 \\
4. & ACD & 0.33 & - & 0.33 & 0.33 & - & 30.71424 \\
5. & CDE & - & - & 0.33 & 0.33 & 0.33 & 31.47833 \\
\hline
\end{tabular}

Sumber: Data diolah

Keterangan :

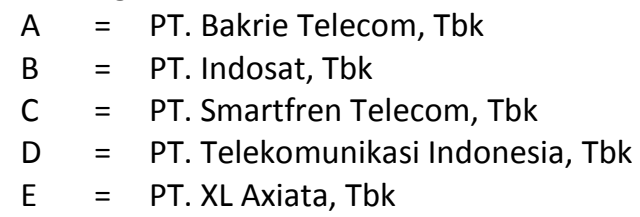

Dari hasil perhitungan portofolio optimal kombinasi 3 saham, menunjukkan bahwa kombinasi saham yang paling optimal adalah kombinasi perusahaan dengan CV terkecil yaitu kombinasi PT. Bakrie Telecom, Tbk, PT. Telekomunikasi Indonesia, Tbk, dan PT. XL Axiata, Tbk dengan nilai CV sebesar 21.48. 
Tabel 10. Peringkat portofolio optimal kombinasi 4 saham

\begin{tabular}{cccccccc}
\hline \multirow{2}{*}{ No } & Kombinasi & \multicolumn{7}{c}{ Proporsi Dana (\%) } & \multirow{2}{*}{ CV } \\
\cline { 3 - 6 } & Saham & A & B & C & D & E & \\
\hline 1. & ACDE & 0.25 & - & 0.25 & 0.25 & 0.25 & 20.43406 \\
2. & ABCE & 0.25 & 0.25 & 0.25 & - & 0.25 & 22.45405 \\
3. & ABDE & 0.25 & 0.25 & - & 0.25 & 0.25 & 22.49826 \\
4. & BCDE & - & 0.25 & 0.25 & 0.25 & 0.25 & 30.47435 \\
5. & ABCD & 0.25 & 0.25 & 0.25 & 0.25 & - & 51.47344 \\
\hline
\end{tabular}

Sumber: Data diolah

Keterangan :
$\mathrm{A}=\mathrm{PT}$. Bakrie Telecom, Tbk
$\mathrm{B}=\mathrm{PT}$. Indosat, Tbk
C $=$ PT. Smartfren Telecom, Tbk
$\mathrm{D}=\mathrm{PT}$. Telekomunikasi Indonesia, Tbk
$\mathrm{E}=\mathrm{PT} . \mathrm{XL}$ Axiata, Tbk

Dari hasil perhitungan portofolio optimal kombinasi 4 saham, menunjukkan bahwa kombinasi saham yang paling optimal adalah kombinasi perusahaan dengan CV terkecil yaitu kombinasi PT. Bakrie Telecom, PT. Smartfren Telecom, Tbk, PT. Telekomunikasi Indonesia, dan PT. XL Axiata dengan nilai CV sebesar 20.43.

Tabel 11. Peringkat portofolio optimal kombinasi 5 saham

\begin{tabular}{|c|c|c|c|c|c|c|c|}
\hline \multirow{2}{*}{ No } & \multirow{2}{*}{$\begin{array}{c}\text { Kombinasi } \\
\text { Saham }\end{array}$} & \multicolumn{5}{|c|}{ Proporsi Dana (\%) } & \multirow{2}{*}{ CV } \\
\hline & & A & B & $\mathbf{C}$ & D & $\mathbf{E}$ & \\
\hline 1. & $\mathrm{ABCDE}$ & 0.2 & 0.2 & 0.2 & 0.2 & 0.2 & 60.8929 \\
\hline
\end{tabular}

Sumber: Data diolah

Keterangan :

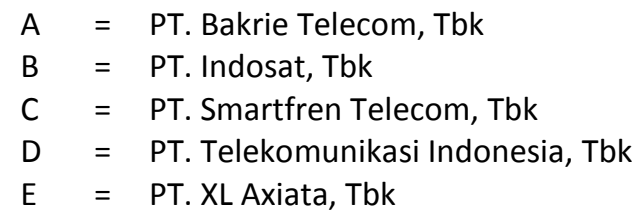

Dari hasil perhitungan portofolio optimal kombinasi 5 saham menghasilkan nilai CV sebesar 60.89 yang terdiri dari saham PT. Bakrie Telecom, Tbk, PT. Indosat, Tbk, PT. Smartfren Telecom, Tbk, PT. Telekomunikasi Indonesia, Tbk, dan PT. XL Axiata, Tbk.

III.5. Penentuan Peringkat Portofolio Optimal dari Semua Kombinasi dengan Equally Weighted Method

Penentuan protofolio yang paling optimal adalah dengan pemeringkatan kombinasi portofolio optimal bedasarkan nilai Coefficient of Variance (CV) terkecil. Berikut ini disajikan hasil pemeringkatan portofolio optimal berdasarkan Coefficient of Variance (CV) terkecil dari kombinasi 2 saham sampai dengan kombinasi 5 saham. Tabel 12 menggambarkan peringkat kombinasi portofolio paling optimal dari masingmasing kategori kombinasi 2 saham sampai dengan kombinasi 5 saham. Dari lima peringkat diatas, dapat dilihat bahwa portofolio yang paling optimal dari semua kombinasi portofolio adalah portofolio saham dengan kombinasi 2 saham, yaitu saham A (PT. Bakrie Telecom, Tbk) dan saham E (PT. XL Axiata, Tbk). Kombinasi saham ini 
memiliki proporsi dana masing-masing saham sebesar $50 \%$, dengan nilai CV sebesar 11.83.

Tabel 12. Peringkat portofolio optimal kombinasi 2 saham sampai dengan 5 saham

\begin{tabular}{clcccccc}
\hline \multirow{2}{*}{ No } & $\begin{array}{l}\text { Kombinasi } \\
\text { Saham }\end{array}$ & A & B & C & D & E & \multirow{2}{*}{ CV } \\
\hline 1. & AE & 0.5 & - & - & - & 0.5 & 11.83798 \\
2. & ADE & 0.33 & - & - & 0.33 & 0.33 & 21.47798 \\
3. & ACDE & 0.25 & - & 0.25 & 0.25 & 0.25 & 20.43406 \\
4. & ABCDE & 0.2 & 0.2 & 0.2 & 0.2 & 0.2 & 60.8929 \\
\hline
\end{tabular}

Sumber: Data diolah

Keterangan :

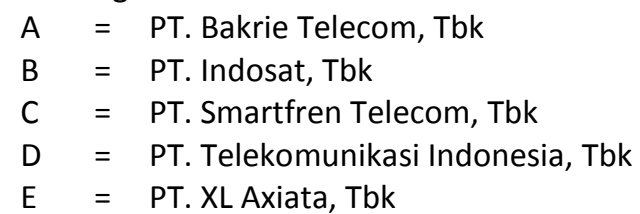

\section{Kesimpulan}

Penelitian ini bertujuan untuk menemukan bukti empiris menggunakan analisis portofolio untuk mendapatkan alternatif investasi saham yang menghasilkan expected return saham yang optimal dan meminimalkan risiko investasi. Dari hasil penentuan contoh, terdapat lima perusahaan yang dapat dibentuk menjadi portofolio saham dengan kombinasi antara 2 saham sampai dengan 5 saham. Penentuan portofolio optimal dilakukan dengan Single Index Model dan Equally Weighted Method.

Dari semua kombinasi saham yang dapat dibentuk, kemudian diperingkat berdasarkan nilai Coefficient of Variance (CV). Portofolio yang paling optimal adalah portofolio yang memiliki nilai CV terkecil. Dari hasil pemeringkatan portofolio optimal berdasarkan Coefficient of Variance (CV) terkecil dari kombinasi 2 saham sampai dengan kombinasi 5 saham dengan menggunakan Single Index Model menunjukkan bahwa kombinasi 2 saham memiliki nilai CV terkecil yaitu kombinasi saham untuk PT. Bakrie Telecom, Tbk dan saham PT. XL Axiata, Tbk dengan proporsi dana saham A $60.4 \%$ dan saham E 39.6\% dengan nilai CV sebesar 11.95. Sedangkan penentuan portofolio dengan menggunakan Equally Weighted Method menunjukkan bahwa kombinasi 2 saham memiliki nilai CV terkecil yaitu kombinasi saham untuk PT. Bakrie Telecom, Tbk dan saham PT. XL Axiata, Tbk dengan proporsi dana masing-masing saham $50 \%$ dengan nilai CV sebesar 11.84 .

\section{Daftar Pustaka}

Astuti D, Sugiharto T. 2005. Analisis pembentukan portofolio optimal pada perusahaan industri plastic and packaging yang terdaftar di Bursa Efek Jakarta studi kasus (1999-2003). Proceeding, Seminar Nasional PESAT; 2005 Agustus 23-24; Jakarta, Indonesia. hIm 251-260.

Burgess CR, Bey PR. 2014. Optimal portfolio: Markowitz full covariance versus simple selection rule. The Journal of Financial Research, 11(2): 153-163. DOI: $10.1111 /$ j.1475-6803.1988.tb00077.x 
Harmono. 1999. Analisis portofolio saham untuk menentukan return optimal dan risiko minimal. Simposium Nasional Akuntansi II. Jakarta (ID): Pusat Data Ekonomi dan Bisnis Universitas Indonesia.

Jogiyanto. 2003. Teori Portofolio dan Analisis Investasi. Edisi Ketiga. Jakarta (ID): BPFE.

Lakonishok J, Shapiro AC. 1984. Stock returns, beta, variance and size: An empirical analysis. Financial Analysts Journal, 40: 36-41.

Pettengill GN, Sundaram S, Mathur I. 1995. The conditional relation between beta and returns. The Journal of Financial and Quantitative Analysis, 30(1): 101-116.

Sudaryanto B. 2001. Pemilihan Portofolio Optimal Indeks Saham LQ-45 di Bursa Efek Jakarta. Semarang (ID): Universitas Diponegoro.

Utomo W. 2007. Analisis Pengaruh Beta dan Varian Return Saham terhadap Return Saham. Semarang (ID): Universitas Diponegoro.

Wardani MK. 2010. Pembentukan Portofolio Saham-Saham Perusahaan yang Terdaftar di Jakarta Islamic Index (JII). Semarang (ID): Universitas Diponegoro.

Winarto EM. 2007. Strategi Portofolio Optimal Menggunakan Single Indeks Model Saham-Saham LQ-45 BEJ Periode 2002-2005. Yogyakarta (ID): Universitas Gajah Mada. 